\title{
WORK SAFETY AND THE RELEVANCE OF TRAINING OF PERSONAL PROTECTIVE EQUIPMENT (PPE) IN THE CIVIL CONSTRUCTION INDUSTRY (CCI)
}

\author{
Valquiria Delani Alves Dias ${ }^{1}$, David Barbosa de Alencar ${ }^{2}$, Fábio Soares de Oliveira ${ }^{3}$, Maria \\ Cristiane Bandeira Santos ${ }^{4}$ and Camily Murrieta Vasconcelos Oliveira Bezerra ${ }^{5}$
}

1,2,3,4 Blauro Cardoso de Mattos Higher Education Institute - FASERRA. Manaus-Amazonas, Brazil.

${ }^{5}$ Nilton Lins University. Manaus-Amazonas, Brazil.

Email: valquiria.delani7@email.com; david002870@hotmail.com, fbsoares171@gmail.com, cristiane.engenheiracivil@gmail.com, camilymv@hotmail.com

Received: Aug $23^{\text {th }}, 2019$

Accepted: Aug 30th 2019

Published: December 02 ${ }^{\text {th }}, 2019$

Copyright (02016 by authors and Galileo Institute of Technology and Education of the Amazon (ITEGAM).

This work is licensed under the Creative Commons Attribution International License (CC BY 4.0).

https://creativecommons.org/licen ses/by/4.0/

\begin{abstract}
The Civil Construction is one of the sectors of economic activity that most absorbs accidents at work and where the risk of accidents is higher. The theme of safety and health in construction is relevant not only because it is a dangerous activity, but also, above all, because the prevention of work-related accidents requires specific focus, both by the particular nature of construction work and by the temporary character of the work centers (works). The purpose of this study is to present this topic in such a way as to highlight its contributions to the Management of Safety and Health. The data collection was made through a bibliographical review, from which it was possible to study all outstanding prominences in NR 18, noting that this subject is highly favored in terms of providing the human well, both internally and externally to society, as acting in the project phase, providing for security measures in the post, where audits, performance indicators and contractual clauses on safety and health should be provided. I work in relation to the companies that act on the work.
\end{abstract}

Keywords: Safety; Job; Construction; Legislation.

\section{INTRODUTION}

In the history of injury accidents in the construction industry, sub-sector and buildings, it is often argued that injuries are largely due to the injured person's lack of knowledge or skills to perform his or her function safely. Although it is a fact, it is necessary to analyze the environment in which this worker performs his tasks, where in most cases are unhealthy environments, in the presence of all risk agents, from mechanical to biological, as well as the training offered to these workers for the development of their tasks.

It is important that the employee has an integral view of the work in which he participates, the risks involved and the means at his disposal to face them. In Civil Construction, this perception seems even more incomprehensible, since in this sector there is no "defined form of work organization based on models and / or concepts, prevailing a traditional manufacturing-based organization, characterized by using an intermittent production system. on demand, with positional physical arrangement, where, at the time of construction, the construction site is the company itself' [1].
Each work is a particular product, varying in size, amount of labor, equipment, materials, capital invested, content and complexity of the others. The use of workers occurs according to the stages of construction and it is not possible to fix them on the work during its entire execution. Within this context the problem of this study consists of the following question: What is the importance of the training of PPE in a construction site.

In order to answer this question, this study assumes the objective of evaluating the importance of training of PPE in a construction site. In recent years efforts have been made to introduce into the construction industry the Total Quality Management (TQM) that already prevails in other industrial branches. In civil construction, the first moves towards a broad approach to quality control emerged in a more organized way in the early 1990s, due to studies focused on each stage of the design process [1]. The present research intends to highlight the human factor in this system and shows the concern of the worker of the protective measures their physical and mental integrity and how they aggregate in the work organization.

With the progressive increase in population, there is a need for more housing, more workers will be recruited for building 
construction. In proportion to this, the risks arising from the construction made quickly to meet the need are multiplied. This is confirmed by the research of [1], who says that "the task has to be done", having to eliminate any object of interference in productivity.

In most cases of accidents at work, it is observed that the employee is not to blame, and in other cases, there is the fault of the employees, when they do not use the equipment provided to them or when they take certain risks to produce fast, contrary to the employer's safety recommendations.

The research will also contribute to the generation of research sources based on data collected in current articles and published works in order to inform the real practice of this venture at a time when many people have only a vague, sometimes negative idea. which means the importance of job security on a construction site.

\section{BIBLIOGRAPHIC REFERENCE}

The Construction Industry is a representative segment and has a great importance in the Brazilian economy. It differs from other sectors by having particular characteristics, standing out for the amount of activities in its production process [2].

The concept of civil construction, according to [3], is extensive, ranging from soil preparation (earthmoving, soil clearing, rock removal, well drilling, etc.) to final cleaning of the work after its completion. Therefore, it includes: the actual construction, demolition, foundations, painting, coatings, expansion, renovation, restoration and, in some cases, the conservation of the property itself, complementary works and any improvements added to the soil or subsoil.

The Construction Industry plays an important role in the Brazilian economy, as it is one of the major generators of labor [4]. This is a characteristic of this sector, as it always makes up the intense need for labor and, therefore, gains its importance from the social point of view, making it an important source of employment.

For many employees, the construction site is the place of learning of the craft (i.e. many of these workers are in the first job phase) since the construction worker is trained inside the work itself, thus there is a direct relationship between officer and assistant, which brings us back to the dawn of civilization (the craftsman and the apprentice).

Not until the thirteenth century did we find a record on occupational safety, with the Libro del Consulado Del Mar, which issued instructions and rules on accidents with maritime workers. Subsequently, occupational accident standards were developed, especially in Spain, and concern about occupational accidents gradually crossed borders.

Work safety can be defined as a set of diversified measures, especially engineering measures, suitable for the prevention of occupational accidents and used for recognition and control of risks associated with the workplace and the production process [5]. Occupational health, on the other hand, is no longer seen as a simple state of absence of diseases, but as the promotion of a well-being environment generating factors that motivate company employees [6].

[7] clarify that, at first, any element that participates in the work process is potentially a generator of dysfunctions, thus being the causes of accidents, among which we can highlight:

- Unsafe acts: the personal factor of insecurity;

- Unsafe conditions: the environmental condition of insecurity due to materials, equipment, facilities, methods and work organization, among others.
With the arrival of the twentieth century there was a great evolution of the TQM, a true revolution in its considerations, moving from the concept of injuries of the beginning of the century, to the concept of accident losses as pointed out below [7]:

- Interventions about man through medical surveillance;

- Corrective interventions on the material components of the work, i.e. at work sites and equipment.;

- Worker's PPE Interventions.

Currently, a systemic approach to occupational safety and health actions has been sought, integrating it into the overall management of the Construction Industry, which translates into an integrated intervention of workers, all sectors and all dimensions of the workforce. company are involved in the process.

With regard to occupational safety and health, the Construction Industry is still characterized as one of the most problematic sectors of activity due to the high rates of accidents.

\section{MATERIALS AND METHODS}

To choose the theme, it was observed the need for a contextualization about the relevance of training in the family business.

In this work, the deductive method was used, which aims to help the formulation of the guiding questions and their confirmation. The set of systematic and rational activities that, with greater security and economy, allows to achieve the goal - valid and true knowledge - tracing the way to be followed, detecting errors and helping the scientist's decisions.

It is well known that the purpose of exploratory research is to become familiar with a subject that is still little known, little explored. According to [8], the research is exploratory, because "it is performed in an area where there is little accumulated and systematized knowledge". Still, according to the retro author, this is also a bibliographic research because it relies on publications available in the literature on the subject. To confirm the guiding hypotheses presented on the subject, previous academic studies pertinent to the bibliographic review which [9] names a bibliographic research were defined, defining it as:

Still within the methodological context the principle of this study was qualitative research, since it will work predominantly with qualitative data. smaller in the analysis" [10]. It was also necessary to use a case study, which, according to [11], "is characterized by the deep and exhaustive study of one or a few objects, in such a way as to allow their broad and detailed knowledge".

\section{STUDY APPLICATION}

For the application of the study, the documentary analysis and an interview were used. It is noteworthy that the documentary research conducted analyzing the material that was not edited, such as company reports, sector evaluations, Payroll, among others.

In this stage of elaboration and application of the interview about the relevance of training in the Construction Industry (ICC), the exploratory research typology was used, where [12] link to the type of research in which there is little knowledge and literature about the researched theme.

It is noteworthy that the interview used by the author consisted of 10 informal questions where the head of the company is at ease for their answers, data collection took place in March and April 2019, and the treatment of the result was qualitative.

1. What is the economic branch of the company?

2. What are the main products / services offered?

3. How many employees does the company have?

4. What are the main customers? 
5. What are the main suppliers?

6. How is the selection / recruitment process for new employees?

7. Does the company have training programs?

8. What reasons lead employees to participate in training?

9. How often do company training take place?

10 . Does the company have a specific place for training? To mitigate this stage, it was decided to perform three phases: determination of the company's needs, preparation and evaluation of the interview, and finally, application of the interview with the company manager.

In the first part of the interview, a deductive analysis was carried out, where [13] describes that it is a method that "starts from principles recognized as true and indisputable and makes it possible to reach conclusions in a purely formal manner, that is, solely by virtue of their logic" The other steps were elaborated on site.

The author praised the act of not using very specific questions, always having ethics as a differential factor in the research performance, the questions have a neutral character, as a way of not influencing the answers.

\section{RESULTS AND DISCUSSIONS}

C M Construções was founded in 2010 by Mr. Israel Carvalho Martins, who started working with a makeshift repair and refurbishment workshop for general construction and residential and industrial plumbing, electrical services, painting and restoration.

For this, it has partnership with highly regarded suppliers in the domestic market. The result of this, five years of work and dedication to our customers is our personal satisfaction and the honor of being a reference today in the segment in which we operate. C M Construções has a team of contractors that specializes in the following construction, hydraulic, electrical and fine workmanship, professionals capable of solving most of the problems related to the part of renovations in general. Services are being sold and are also starting in the field of fine finishing construction products such as: Metals (simple to the most sophisticated taps and showers), Bathroom Dishes such as sinks, toilets, bathroom accessories, bathtubs of various sizes. and types, Miscellaneous Paints, Floors and Coatings, Electrical Boards, Cabling, Miscellaneous Tools.

In celebration of its five years in the Manaus market, they come with changes in their facilities and a wider and well located area, and also a new feature: equipment rental, to better meet and meet the needs of their customers.

The company has employees specialized in various areas of activity, being only hired as service providers, also has reliable and quality suppliers to ensure the efficiency and effectiveness of its services.

Currently, the staff of C M Construções is composed of only one permanent employee, being Mr. Israel Carvalho Martins, with the function of owner and manager, the other employees are temporary, specialists in various areas of construction.

Regarding management, the radar chart shows strengths in general management of decision-making processes, innovation process, loyal customers, good relationship, financial management and excellent relationship with suppliers. It should be noted that improvements should be made in the use of technologies and information systems, as well as in the strategic means to be adopted for the company, besides that there is no relationship with the government, regarding bidding processes, as it tends to become a very strong point, if the part that will be properly worked out corrected.

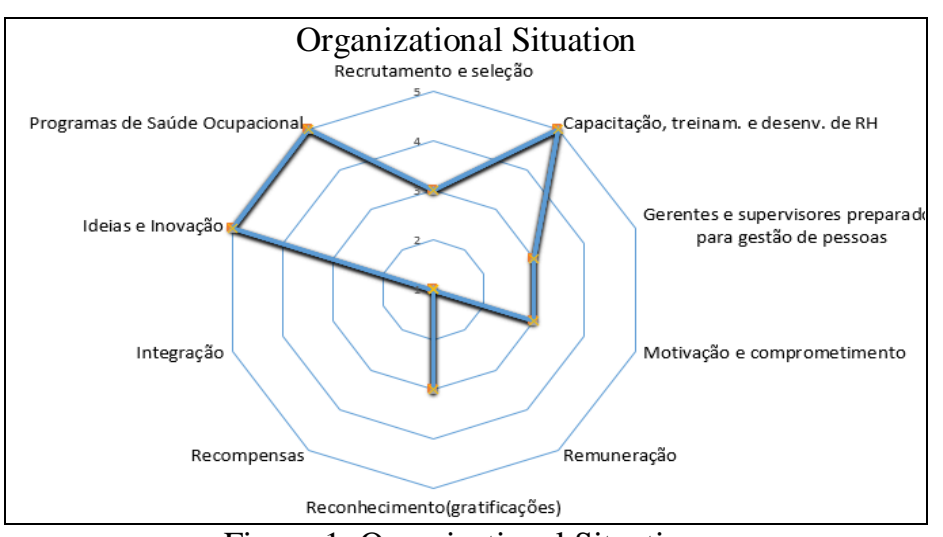

Figure 1: Organizational Situation.

Source: Authors, (2019).

Regarding the HR sector the company has only two employees, the company has the good collaboration of its already qualified outsourced employees, because the company does not have training and HR development courses, we also saw that there are no plans, nor incentives to innovation and occupational health programs, considering that we have only outsourced workers.

Through the radar chart, you can have a more detailed view as in a radiograph of the organization, enabling comparative analysis across sectors and showing the evolution of internal development of the organization as those in which they need to be improved, requiring more attention or the one to keep. The simplified way to represent the result of the organization's internal analysis, the radar chart points out ten internal areas of analysis known as $10 \mathrm{M}$ 's of self-diagnosis, allowing to visualize the comparative situation between them.

To prepare the Radar chart, it is necessary to point out the ten internal areas of the 10-M's self-diagnostics exploring the strengths, weaknesses and points for improvement of the company C M Construções, as shown in the following chart:

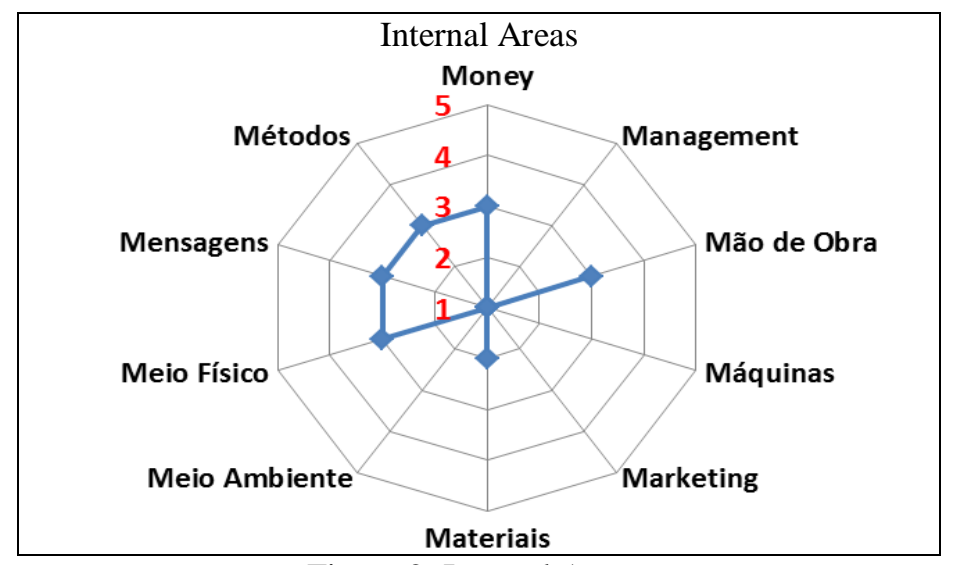

Figure 2: Internal Areas.

Source: Authors, (2019).

Through the radar chart, it can be seen that one of the main problems of the studied organization is the lack of effective manpower, in the case of CM Constructions, as previously mentioned, it works with outsourced workers, so there are no people committed to the progress. of the company and employees dedicated solely to its stability.

It can be noted that the rating chart shows weaknesses in the finance, media, communication, procedures and labor sectors, however, a greater focus will be on labor, the others vary for improvement or strengths. 
One of the main advances of the new text of the NR-18 is the obligation of elaboration by the companies of PCMAT. Its implementation allows effective management of the work environment, the production process and worker orientation, reducing the sharp number of work accidents and occupational diseases [14].

In general, safety programs in this industrial sector have as a priority the prevention of serious and related fatal accidents.

In addition to the Program documents provided for in the NR-18 legislation, it is recommended that the program planning should be based on the main development stages of the project, from projects to final services, considering the risk of accidents and diseases. and the professional category active in each stage.

In the recognition of risks that cause occupational diseases, in addition to physical, chemical and biological agents, we must consider the working conditions at the site due to environmental factors such as rain, humidity, wind speed and height, it is emphasized that all PCMAT It will only be legally valid if it is registered through an ART.

It is ART that must ensure traceability efficiently and effectively, but it is where we most want it in day-to-day practice in engineering works and services. Traceability is the guarantee for the developer, the contracting government and society.

\section{FINAL CONSIDERATIONS}

Since the reformulation of NR-18 in July 1995, which can be considered a milestone in the adoption of the process of reformulation of regulatory standards and policy of action of the MTE, issues related to occupational safety and health in industry. of construction in Brazil have had significant improvements resulting from the parties' involvement and commitment in tripartite discussions.

With this research it can be pointed out that the relationship between safety and health, where occupational safety is defined as a set of diversified measures, while occupational health is the promotion of a well-being environment in the company. The last decades of the twentieth century were of great evolution of occupational health and safety management. There has been a real revolution in its concepts. From the concept of earlycentury injuries to the concept of accident loss.

Construction workers are usually made up of groups of people who perform their work in an unhealthy environment, the fact that work accidents in many cases is possibly also due to misinformation of workers. The programs established by the MTE must be implemented and respected in order to minimize the risks inherent in this sector. PPRA aims to detect risks and inadequate conditions in the workplace that affect workers' health.

The PCMAT at ICC aims to plan the safety and protection actions to be adopted in each phase of the construction project, while the PCMSO aims to perform workers' admission, periodic and dismissal examinations.

Among the determinations of NR-18 combined with resolution 437/99 is worker training prior to commencing work on a site. This is a six-hour admission training. During the course, workers learn safety standards and learn about the company's way of working, as well as the specific laws for the safety and health of workers.

It is also noteworthy that the implementation of the training program or implementation of results depends on some factors, such as: adequacy of the program to the needs of the organization and the participants; quality of the material presented; cooperation of company managers and directors; trainee motivation to learn; trainee learning ability; practical application and time to assimilate what has been learned; preparation of the training material, which should be significant, among others, all these methods must be varied, innovative and transferable to the work.

Finally, it is emphasized that all employees involved should be aware of the importance of PPE, regardless of the hierarchy established at the construction site, as good work in this direction will result in the reduction of work accidents.

\section{REFERENCES}

[1] Gomes, Maria de Lourdes Barreto. Organização do Trabalho na Construção Civil: Subsetor Edificações e Condições de Trabalho. In: Apostila da disciplina Organização da Produção do Curso de Especialização em Engenharia de Segurança do Trabalho. João Pessoa: DEP/PPGEP, 2013.

[2] Beling, Adriana. Implicações decorrentes da Opção em Contratar Mão-De-Obra Terceirizada em uma Empresa de Construção Civil. Monografia apresentada a Universidade Federal de Santa Catarina. Florianópolis: UFSC, 2019.

[3] Santos, Tânia Euridice dos Santos Nogueira, et al. Análise dos impactes ambientais da exploração de ouro: caso de estudo da mina de Chipindo, Angola. 2018. PhD Thesis.

[4] Oliveira, Valeria Faria; Oliveira, Edson Aparecido de Araújo Querido. O papel da Indústria da Construção Civil na organização do espaço e do desenvolvimento regional. In: IV Congresso Internacional de Cooperação Universidade-Indústria. 2012.

[5] Masculo, Francisco Soares; Vidal, Mario Cesar. Ergonomia: trabalho adequado e eficiente. Elsevier Brasil, 2013.

[6] Melo, Maria Bernadete Fernandes Vieira de. Influência da Cultura Organizacional no Sistema de Gestão da Segurança e Saúde no Trabalho em Empresas Construtoras. (Tese para obtenção do Título de Doutora em Engenharia de Produção), João Pessoa, DEP/PPGEP, 2013.

[7] Pinheiro, F. A.; Gomes, M. L. B. Percepção do trabalhador sobre a organização do trabalho e gestão de segurança e saúde do trabalho no subsetor edificações: estudo de caso. In: XII SIMPEP. Bauru, SP. 2015.

[8] Vergara, Sylvia Constant. Projetos e Relatórios de Pesquisa em Administração $10^{\circ}$ ed. Atlas. 2013.

[9] Severino, Antônio Joaquim. Metodologia do trabalho científico. Cortez editora, 2017.

[10] Lakatos, E. M.; Marconi, M. de A. Fundamentos de Metodologia Científica Editora Atlas. 2017.

[11] De Oliveira, Maxwell Ferreira. Metodologia científica: um manual para a realização de pesquisas em Administração. Universidade Federal de Goiás. Catalão-GO, 2011.

[12] Beuren, Ilse Maria Ilse. Como elaborar trabalhos monográficos em contabilidade. Editora Atlas SA, 2013. 
[13] Rodrigues, M.; Pacievitch, C.; GIL, C. Ensino de História e Teoria e Metodologia da História: miradas a partir do Pibid. História Hoje, 2017, 6.11: 325-348.

[14] Lima Júnior, Jófilo Moreira. Segurança e saúde no trabalho da construção: experiência brasileira e panorama internacional. In: OIT - Secretaria Internacional do Trabalho. Brasília. 2015. 